\title{
KONSEP DIRI DAN KENAKALAN REMAJA PADA ANAK JALANAN
}

\author{
Helmita Asima Manalu ${ }^{1}$, Doddy Hendro Wibowo ${ }^{2}$ \\ Fakultas Psikologi, Universitas Kristen Satya Wacana ${ }^{1,2}$ \\ Jl. Diponegoro 52-60, Salatiga 50711, Jawa Tengah \\ Surel : helmitamanalu@gmail.com ${ }^{1}$, doddy.hendro@gmail.com²
}

\begin{abstract}
The phenomenon of street children is a problem that has become a worldwide concern because of the increasing number. This study aims to determine the relationship between self-concept and juvenile delinquency in street children. This research was conducted in the city of Salatiga with the number of respondents as many as 34 teenagers with a quantitative descriptive approach. The sampling technique used is the technique Accidental Sampling. The results found in this study are the relationship between self-concept and juvenile delinquency in street children with a value obtained of -0.572 with a sig of 0.000 . With this, that juvenile delinquency in street children is not a stand-alone situation but is a combination of several conditions experienced by street children, if a street child does not get direction from their parents and education, then delinquency in street children is a unavoidable problem.
\end{abstract}

Keywords: : Juvenile Delinquency, Street Children, Self Concept.

\begin{abstract}
Abstrak : Fenomena anak jalanan merupakan suatu masalah yang menjadi perhatian dunia karena jumlahnya yang cukup meningkat. Penelitian bertujuan untuk mengetahui hubungan konsep diri dan kenakalan remaja pada anak jalanan. Penelitian ini dilakukan di daerah kota Salatiga dengan jumlah responden sebanyak 34 orang remaja dengan pendekatan deskriptif kuantitatif. Teknik sampling yang digunakan adalah teknik Accindental Sampling. Hasil yang ditemukan dalam penelitian ini adalah adanya hubungan konsep diri dan kenakalan remaja pada anak jalanan dengan nilai yang diperoleh sebesar -0.572 dengan sig 0,000 . Dengan ini bahwa kenakalan remaja pada anak jalanan bukanlah suatu keadaan yang berdiri sendiri tetapi merupakan perpaduan dari beberapa kondisi yang dialami oleh anakanak jalanan, jika seorang anak jalanan tidak mendapatkan pengarahan dari orang tua dan juga pendidikan mereka, maka kenakalan pada anak jalanan merupakan suatu masalah yang tidak bisa dihindarkan lagi.
\end{abstract}

Kata kunci : Kenakalan remaja, Anak jalanan, Konsep diri.

\section{PENDAHULUAN}

Anak jalanan adalah anak yang menghabiskan sebagian besar waktunya untuk melakukan aktivitas hidup sehari-hari di jalanan, baik saat mencari nafkah atau berkeliaran di jalan dan kawasan-kawasan umum lainnya (Despos RI dalam purwoko, 2013). Anak jalanan menghabiskan sebagian besar waktunya untuk melakukan aktivitas hidup sehari-hari di sekitar jalanan, baik ketika 
mencari nafkah dan juga untuk bersenangsenang. Fenomena anak jalanan sudah ada sejak lama dan selalu terus berkembang dan mengakibatkan meningkatnya jumlah anak jalanan di berbagai sudut kota yang sebagian besar dikarenakan krisis ekonomi (Pardede 2008). Sebagai besar anak jalanan berasal dari keluarga miskin yang tidak mempunyai kemampuan untuk memberdayakan dirinya, sehingga rentan terhadap kenakalan remaja. Permasalahan yang seringkali ialah terjadi perkelahian, penggunaan narkoba, pencurian serta prostitusi anak jalanan. Anak jalanan lebih mudah terpengaruh oleh kebiasaan buruk budaya di jalanan, terutama seks bebas dan penyalahgunaan narkoba. Mirisnya, seringkali anak jalanan mendapat kekerasan baik secara fisik, psikologis maupun seksual. Mereka benar-benar menganggap jalanan sebagai tempat bermain yang menyenangkan yang tidak banyak aturan (Lubis Hotland \& Hodriani 2016).

Sebagian anak jalanan sering ditemui di perempatan lampu merah. Anak biasanya sambil mengamen di siang hari maupun malam hari. Penampilan mereka yang terlihat tidak rapi dalam berpakain seperti memakai baju seluruh baju yang berwarna hitam, gaya rambut yang warna-warna terang yang mencolok dipadukan dengan baju yang lusuh. Terkadang anak jalanan juga melakukan tindakan yang membuat resah masyarakat setempat seperti: mencuri, perkelahian, berjudi dan juga mabuk-mabukan. Hal ini dapat dilihat seorang anak jalanan Salatiga yang mengalami pengeroyokan oleh sekelompok sesama anak jalanan. Salah satu dari seorang anak jalanan nekat menyiram bensin pada tubuh temannya dan membakarnya hidup-hidup. Ia juga menusukkan benda tajam pada tubuh lawannya yang menyebabkan luka bagian dalam belakang tubuh telinga dan tangan. korban mengalami luka bakar di bagian punggung, dada, dan perut. Korban berkata bahwa ia dikeroyok lalu dibakar oleh sekelompok anak jalanan (https://www.tribunnews.com/regional/2020/ 03/09/kronologi-anak-punk - dibakar- hiduphidup-di-s alatiga- awalnya - ngamen-mampirke-tempat-tongkrongan) Menurut Direktorat Kesehatan Jiwa (2007), faktor mengakibatkan anak remaja turun ke jalanan adalah faktor ekonomi yang kurang, dengan alasan agar bisa menghasilkan uang bagi dirinya dan bagi keluarganya. Selain itu, faktor-faktor lainnya yaitu berasal dari keluarga seperti menghindari masalah yang terjadi di dalam keluarga, menghindari pekerjaan yang ada di dalam rumah, kurangnya ilmu pengetahuan dalam mendidik anak serta kurangnya perhatian dan tanggung jawab orang tua, masalah perilaku orang tua saat mendidik anak seperti kekerasan atau penganiayaan anak.

Data kenakalan remaja di Indonesia dari tahun ke tahun terus meningkatan. Dari badan 
Pusat Statistik (BPS) pada tahun 2013 jumlah kenakalan remaja di indonesia mencapai 6325 kasus, sedangkan pada tahun 2014 jumlahnya mencapai 7007 dan kasus 2015 mencapai 7762 kasus. Prediksi tahun 2016 mencapai 8597,97 kasus, 2017 sebesar 9523.97 kasus, 2018 sebanyak 10549,70 kasus 2019 mencapai 11685,90 kasus 2020 mencapai 12944,47 kasus. Mengalami kenaikan tiap tahunnya sebesar $10,7 \%$. kasus tersebut terdiri dari berbagai kasus kenakalan remaja diantaranya pencurian, pergaulan bebas, narkoba dan perkelahian. Dari data yang diperoleh angka kenakalan remaja terus mengalami peningkatan tiap tahunnya (S Rahmi.P.F \& Oktaviani, Y. 2019).

Anak jalanan merupakan masalah yang sering ditemui di berbagai kota, salah satunya ialah kota Salatiga. Berdasarkan hasil wawancara yang dilakukan dengan anak jalanan di Salatiga, diantaranya menyatakan bahwa alasan mereka menjadi anak jalanan adalah mereka ingin mencari jati diri sendiri, ingin merasakan kebebasan tanpa terikat dengan siapapun. Anak jalanan yang menggunakan pakaian lusuh atau serba hitam, menggunakan tato, merokok dan meminumminuman keras alasannya adalah agar mereka terlihat berbeda dengan anak yang lainnya dan memiliki ciri khas dari anak jalanan tersebut. Mereka juga mengatakan pandangan diri mereka untuk menjadi seorang anak jalanan adalah supaya mereka dapat melakukan apapun yang mereka inginkan tanpa melihat aturan yang ada seperti remaja pada umumnya. Selain itu, anak jalanan juga mengatakan bahwa mereka juga terlibat dalam penggunaan narkoba dan melakukan hubungan seks bebas yang mengakibatkan anak perempuan jalanan yang berusia remaja hamil di luar nikah. Namun hal tersebut tidak membuat mereka berhenti untuk menjadi anak jalanan, melainkan mereka nyaman dengan kehidupan yang bebas dan dapat melakukan apa saja yang mereka sukai. Berdasarkan hal ini, peneliti berasumsi bahwa anak jalanan Salatiga tidak mampu menggambarkan diri mereka baik secara fisik, psikologis, sosial dan emosional yang akhirnya mengakibatkan masuk ke dalam pergaulan kenakalan remaja.

Masa remaja adalah periode transisi dari masa anak ke masa dewasa yang berjalan antara 11 sampai 21 tahun. Pada periode ini anak mengalami pertumbuhan maupun perkembangan fisik maupun perkembangan psikis. Mereka bukan lagi anak-anak baik dalam bentuk badan maupun cara berfikir dan bertindak, tetapi bukan pula orang dewasa yang telah matang. Upaya untuk menemukan identitas mereka kali menimbulkan banyak permasalahan (Karyati 2017). Masa remaja merupakan periode yang menghadirkan banyak tantangan, karena pada masa remaja terjadi banyak perubahan yang harus dihadapi mulai perubahan fisik, biologis, psikologis, dan juga sosial. Remaja melihat gambaran diri 
mereka, kemudian mereka melakukan perbandingan terhadap orang lain. ketika seorang remaja menilai dirinya secara positif maka mereka memiliki konsep diri yang tinggi. Sebaliknya, jika seorang remaja memandang dirinya secara negatif maka remaja akan memiliki konsep diri yang rendah (Papilia, Olds, dan Feldman 2004). Maka dari itu, perlu untuk menerapkan konsep diri yang tinngi terhadap masing-masing individu. Konsep diri merupakan faktor yang penting bagi pembentukan tingkah laku manusia. Manfaat individu mengetahui konsep diri adalah mereka dapat menampilkan perilaku yang diterima dari respon-respon dan pandangan-pandangan yang diberikan oleh orang lain (Pamuchitia dan Panjaitan, 2010).

Razali (2013) mengatakan bahwa konsep diri adalah persepsi diri tentang kekuatan, kelemahan, keadaan pikiran, dan nilai dengan sosial lingkungan. Perilaku seseorang dapat dijelaskan secara substansial oleh konsep diri, yang dipengaruhi oleh identitas diri, penilaian orang lain dan persepsi sosial dengan orang lain. Setiap individu harus memiliki konsep tertentu di dalam dirinya apakah itu konsep diri yang positif maupun konsep diri yang negatif. Konsep diri yang positif dapat diperoleh dengan cara menanamkan nilai-nilai agama yang kuat, kepercayaan diri yang tinggi, dan juga menerima diri apa adanya. Sedangkan, seseorang yang memiliki konsep diri yang negatif disebabkan karena kurangnya perhatian, tidak mendapatkan kasih sayang, kurangnya kepercayaan diri, dan tidak dapat menerima diri mereka apa adanya. Hal ini dapat dilihat ketika seseorang berpandangan negatif maka akan muncul pandangan yang negatif. Sebaliknya ketika seseorang berpandangan positif maka akan muncul pandangan yang positif pula konsep diri yang dimiliki (Ghusfron M dan Risnawati R 2017). Konsep diri anak jalanan berbeda dengan konsep diri anak pada umumnya. Menurut Mandel \& Smeesters, D (2008) konsep diri yang negatif merupakan salah satu faktor terjadinya kenakalan remaja. Ketika remaja memiliki konsep diri yang negatif, maka dalam perkembangannya remaja melihat lingkungan, orang tua dan kehidupan secara negatif.

Konsep diri anak jalanan berbeda dengan konsep diri dengan pada anak remaja pada umumnya. Hal ini dikarenakan anak jalanan memeliki latar belakang yang berbeda secara sosial ekonomi dengan anak-anak lain. Oleh karena itu, perlu untuk menerapkan konsep diri yang kuat dari setiap individu karena manusia sejak lahir memiliki perlindungan untuk hidup di masyarakat (Sudarsono, 2005). Namun salah satu hal yang paling menentukan ialah cara pandang seorang terhadap diri dirinya sendiri. Semakin individu berpandangan negatif, semakin sering muncul konsep-konsep yang negatif tentang dirinya sendiri. Sebaliknya semakin seseorang 
berpandang positif mempunyai pandangan yang positif terhadap dirinya sendiri, semakin positif pula konsep diri yang ia miliki (Riyadi Agus 2016).

Berdasarkan penelitian yang dilakukan Pardede (2008) hasil penelitian menunjukan bahwa konsep diri yang terbentuk pada anak jalanan adalah konsep diri yang negatif. Berdasarkan penelitian sebelumnya yang dilakukan oleh Purwanto (2017) menyatakan bahwa anak jalanan merasa percaya diri dengan penampilan mereka dan memiliki harga diri serta kapasitas yang memumpuni sebagai anak jalanan. Dalam penelitian yang dilakukan Kurniasari, Khasanah, Kalimah (2019) berdasarkan hasil penelitian, dinyatakan anak jalanan hidup dalam ruang tanpa aturan yang menyebabkan pembentukan konsep diri yang negatif. Konsep diri negatif tersebut yang menjadi landasan utama perilaku negatif sehingga menyebabkan perilaku kenakalan remaja salah satunya adalah perilaku seksual pranikah. Dalam penelitian yang dilakukan Mahanani Putri (2010) menunjukan anak jalanan memiliki konsep diri yang negatif, hal ini dapat dilihat dengan adanya perasaan cemas, takut bergaul, rendah diri, gambaran masa depan tidak jelas dan memiliki perilaku menyimpang.

Berdasarkan fenomena diatas, penulis ingin mengetahui bagaimana hubungan antara konsep diri dengan kenakalan remaja pada anak jalanan di Salatiga, dengan tujuan apakah ada hubungan antara konsep diri dengan kenakalan remaja pada anak jalanan di Salatiga. Dari latar belakang yang sudah diuraikan penulis, perbedaan dan hasil penelitian ilmiah yang telah dihasilkan dan penjelasan-penjelasan teoritis yang diajukan para penulis sebelumnya, peneliti tertarik meneliti kembali mengenai konsep diri remaja anak jalanan, mengingat dalam kenyataannya peningkatan jumlah anak jalanan di indonesia dalam beberapa tahun ini merupakan fenomena sosial yang perlu mendapatkan perhatian serius dari berbagai pihak. Maka peneliti tertarik untuk melakukan penelitian mengenai "Hubungan Konsep diri Dan Kenakalan Remaja Pada Anak Jalanan Salatiga" namun dengan menggunakan sampel dan tempat penelitian yang berbeda dari yang digunakan peneliti-peneliti sebelumnya.

\section{METODOLOGI PENELITIAN}

Metode yang digunakan dalam penelitian ini adalah metode penelitian kuantitatif. menurut Sugiyono (2017) penelitian kuantitatif dapat diartikan sebagai metode penelitian yang berlandaskan pada filsafat positivisme, digunakan untuk meneliti digunakan untuk meneliti pada populasi atau sampel tertentu, teknik pengambilan sampel pada umumnya dilakukan secara random, pengumpulan data menggunakan instrumen penelitian, analisis data bersifat kuantitatif/statistik dengan tujuan untuk menguji hipotesis yang telah ditetapkan. Populasi dalam penelitian adalah anak 
jalanan yang terlihat di lampu merah, terminal dan emperan toko.

Dipandang orang kebetulan ditemui cocok sebagai sumber data (Sugiyono, 2013). Responden yang terlibat dalam penelitian ini merupakan anak remaja yang terlibat di jalanan. Berdasarkan karakteristik demografi anak jalanan yang berjenis kelamin Laki-laki sebanyak 70,5\%, berjenis kelamin perempuan sebanyak $2,9 \%$, dengan usia 12-15 tahun sebanyak $11,7 \%$, usia $16-18$ tahun sebanyak $38,2 \%$, usia $19-21$ sebanyak $50 \%$, lama di jalanan 1 tahun sebanyak 2,9\%, lama dijalanan 2 tahun 5,8\%, lama dijalanan 3 tahun 23,5\%, 4 tahun dijalanan sebanyak 14\%, 5 tahun dijalanan 14,7\%, lama dijalanan 6 tahun 11,7\%, lama dijalanan 7 tahun 14,7\%, lama dijalanan 8 tahun 2,9\%, lama dijalanan 9 tahun 2,9\%.

Pengumpulan data yang dilakukan dengan mengunakan angket. Angket ini berupa daftar pertanyaan yang harus dijawab dan diisi oleh sejumlah subjek yang sudah disediakan dan angket yang diberikan harus dijawab sesuai dengan instruksi yang diberikan oleh peneliti. Angket ini disusun berdasarkan skala yang digunakan berpedoman pada skala likert yang telah dimodifikasi. Skala ini terdiri aitem yaitu aitem favorable dan skala aitem unfavorable. Skala kenakalan anak jalanan yang digunakan mengacu pada aspek-aspek yang diungkapkan menurut Chadwick dan Top (1993) yaitu pelanggaran terhadap orang, pelanggaran terhadap status dan pelanggaran terhadap barang. Skala kenakalan remaja pada anak jalanan terdiri dari 32 pernyataan yang seluruhnya favorable. Skala konsep diri digunakan untuk mengungkapkan sejauh mana tingkat konsep diri yang dimiliki oleh subjek penelitian. Skala konsep diri yang digunakan mengacu pada aspek-aspek yang dibuat oleh Fitts (1996) yaitu Diri Fisik, Diri Psikis, Diri Sosial dan Diri Etik-Moral. Skala konsep diri ini berjumlah 33 aitem yang terdiri dari favorable dan unfavorable. Sampel adalah sebagian dari populasi (Azwar, 2007). Arikunto (2006) juga menyatakan, sampel adalah sebagian atau wakil populasi yang diteliti.pada penelitian ini besarnya populasi tidak dapat diketahui secara pasti, sehingga penulis memilih teknik pengambilan sampel menggunakan teknik Accindental Sampling. Accindental Sampling merupakan teknik penentuan sampel berdasarkan kebetulan yakni siapa saja yang secara kebetulan bertemu dengan peneliti dapat dijadikan sebagai sampel, bila dipandang orang kebetulan ditemui cocok sebagai sumber data (Sugiyono, 2013).

Responden yang terlibat dalam penelitian ini merupakan anak remaja yang terlibat di jalanan. Berdasarkan karakteristik demografi anak jalanan yang berjenis kelamin Laki-laki sebanyak 70,5\%, berjenis kelamin perempuan sebanyak 2,9\%, dengan usia $12-15$ tahun sebanyak $11,7 \%$, usia 16 18 tahun sebanyak $38,2 \%$, usia 19-21 sebanyak $50 \%$, lama di jalanan 1 tahun sebanyak 2,9\%, lama dijalanan 2 tahun 5,8\%, lama dijalanan 3 tahun 23,5\%, 4 tahun dijalanan sebanyak 14\%, 5 tahun dijalanan 14,7\%, lama dijalanan 6 tahun 11,7\%, lama dijalanan 7 tahun $14,7 \%$, lama dijalanan 8 tahun $2,9 \%$, lama dijalanan 9 tahun $2,9 \%$.

Pengumpulan data yang dilakukan dengan mengunakan angket. Angket ini berupa daftar pertanyaan yang harus dijawab dan diisi oleh sejumlah subjek yang sudah disediakan dan angket yang diberikan harus dijawab sesuai dengan 
instruksi yang diberikan oleh peneliti. Angket ini disusun berdasarkan skala yang digunakan berpedoman pada skala likert yang telah dimodifikasi. Skala ini terdiri aitem yaitu aitem favorable dan skala aitem unfavorable. Skala kenakalan anak jalanan yang digunakan mengacu pada aspek-aspek yang diungkapkan menurut Chadwick dan Top (1993) yaitu pelanggaran terhadap orang, pelanggaran terhadap status dan pelanggaran terhadap barang. Skala kenakalan remaja pada anak jalanan terdiri dari 32 pernyataan yang seluruhnya favorable. Skala konsep diri digunakan untuk mengungkapkan sejauh mana tingkat konsep diri yang dimiliki oleh subjek penelitian. Skala konsep diri yang digunakan mengacu pada aspek-aspek yang dibuat oleh Fitts (1996) yaitu Diri Fisik, Diri Psikis, Diri Sosial dan Diri Etik-Moral. Skala konsep diri ini berjumlah 33 aitem yang terdiri dari favorable dan unfavorable.

\section{HASIL DAN PEMBAHASAN}

Pada hasil uji reabilitas, diketahui bahwa variabel kenakalan pada anak remaja memiliki Cronbach's alpha sebesar 0,728 dari batas minimal yang ditetapkan adalah 0.06. sehingga skala Spikologi dalam variabel kenkalan remaja pada anak jalanan dinyatakan reliabel. Berdasarkan tabel 2. Pada hasil uji reliabilitas diketahui bahwa variabel konsep diri memiliki koefisiensi Cronbach's alpha 0,723 dari batas minimal yang ditetapkan adalah 0.06 , sehingga skala psikologi dalam variabel konsep diri dinyatakan reliable.

Pada Hasil uji prasyarat analisis yang berupa uji normalitas sebaran nilai variabel menggunakan SPSS 21 for windows menunjukan harga koefisien
Kolmogorov-Smirnov sebesar $\mathrm{Z}=0,412$ dengan $\mathrm{P}=$ 0.996 untuk variabel Konsep Diri. Sedangkan nilai $\mathrm{Z}=0.716$ dengan $\mathrm{P}=0.684$ untuk variabel Kenakalan Remaja pada anak jalanan. Maka dalam hal ini variabel kenakalan remaja dengan konsep diri memiliki nilai $\mathrm{p}>0,05$ dan dapat dikatakan sebaran nilainya normal sehingga seluruh variabel dalam penelitian ini berdistribusi normal.

Pada hasil Uji Linieritas hubungan antara variabel Konsep diri dengan variabel Kenakalan Remaja Pada anak jalanan menunjukan Nilai signifikikan sebesar 0.691 lebih besar dari 0.05. maka dapat disimpulkan bahwa ada hubungan linear secara signifikan antara variabel Konsep Diri dengan Kenakalan Remaja pada anak jalanan (Y).

Berdasarkan hasil perhitungan uji korelasi product moment person dengan bantuan SPPS 21 dapat diperoleh hubungan sebesar -0.572 dengan sig $0,000 \quad(\mathrm{P}<0,05)$. Hal ini menunjukan adanya korelasi yang negatif signifikan antara konsep diri dengan kenakalan remaja pada anak jalanan khusunya di daerah kota Salatiga.

Berdasarkan hasil analisis hubungan konsep diri dengan kenakalan remaja pada anak jalanan Salatiga diperoleh koefisiensi korelasi sebesar sebesar -0.572 dengan sig 0,000 Karena nilai signifikan lebih kecil dari 0.05 maka hal ini menunjukan bahwa Ho ditolak dan H1 diterima. Sehingga dapat dikatakan bahwa ada hubungan negatif antara konsep diri dengan kenakalan remaja pada anak jalanan. Hasil penelitian sesuai dengan penelitian yang dilakukan oleh Riyadi (2016), dalam penelitiannya bahwa terdapat 
korelasi negatif yang signifikan antara konsep diri dengan kenakalan anak jalanan. Semakin negatif konsep diri maka akan lahirlah pola perilaku yang negatif, dan sebaliknya semakin positif konsep diri maka akan lahirlah pola perilaku yang positif. Hasil penelitian menunjukan bahwa semakin baik konsep diri maka kenakalan remaja anak semakin menurun, begitu sebaliknya, semakin buruk konsep diri maka kenakalan remaja pada anak jalanan maka akan semakin meningkat. Hal ini sesuai dengan yang telah diuraikan oleh Hartina (2019). Konsep diri merupakan aspek penting untuk dipahami di dalam kehidupan, karena konsep diri adalah gambaran tentang diri sendiri melalui hubungan dengan orang lain (Fernanda \& Sano, 2012).

Konsep diri pada anak jalanan yang ada di Kota Salatiga adalah sebagai berikut: kategorisasi Rendah sebanyak 0\%, anak jalanan dalam kategorisasi Sedang sebanyak $67.64 \%$ dan kategorisasi tinggi sebanyak $32.35 \%$, sehingga dapat disimpulkan bahwa anak jalanan yang menjadi subjek penelitian yang ada di kota Salatiga ini memiliki konsep diri yang sedang. Pada kenakalan remaja pada anak jalanan adalah sebagai berikut: Kenakalan remaja pada anak jalanan kategorisasi Tinggi sebanyak 17.64\%, kenakalan remaja pada anak jalanan kategorisasi Sedang $70.58 \%$, kenakalan remaja pada anak jalanan kategorisasi Rendah $11.76 \%$. Hal ini menunjukan bahwa sebagian besar anak jalanan terlibat dalam kenakalan remaja.

Konsep diri seseorang terbentuk dari perasaan apakah dirinya diterima dan diinginkan kehadirannya oleh kelompoknya. Aspek diri yang positif dan negatif yaitu: konsep diri fisik, konsep diri Psikis, konsep diri sosial konsep diri moral. Perasaan inilah yang menjadi landasan dari pandangan, penilian, atau bayangan seseorang mengenai dirinya sendiri yang secara keseluruhan disebut dengan konsep diri (Djaali, 2009). Dengan ini, kenakalan remaja pada anak jalanan bukanlah suatu keadaan yang berdiri sendiri tetapi kombinasi dari beberapa kondisi yang dialami oleh anak remaja pada anak jalanan, jika seorang anak tidak mendapatkan arahan dari orang tua dan juga pendidikan mereka, kenakalan anak-anak jalanan adalah masalah yang tidak bisa dihindari lagi. Dari berbagai faktor penyebab kenakalan anak jalanan, diperlukan upaya yang dapat mengarahkan kehidupan yang harmonis. Salah satu upaya yang dapat dilakukan adalah dapat memberikan bimbingan dan layanan. Anak jalanan merupakan salah satu bagian dari masa depan bangsa sehingga memerlukan pembinaan serta bimbingan yang baik agar mereka dapat bertanggung jawab dan mempunyai konsep diri yang kuat. (Purwoko \& Tjutjup, 2013).

Anak jalanan menganggap penampilan fisik mereka terlihat menarik dan bangga akan penampilan mereka menjadi seorang anak jalanan. Dilihat dari pengamatan, meskipun badan dan fisik mereka yang tidak sesuai dengan pakaian remaja pada umumnya yaitu pakaian yang bersih dan rapi, anak jalanan merasa bahwa secara fisik penampilan mereka terlihat menarik. Bahkan ada juga anak jalanan yang termasuk ke dalam kelompok anak punk yang menambahkan aksesoris tato, tindik di kuping serta rambut yang berwarna-warni (Purwanto 2017). Dalam proses perkembangan masa remaja dibutuhkan konsep diri positif untuk mencapai perilaku yang positif. 
Remaja yang memiliki konsep diri positif akan melakukan perbuatan positif yang yang diharapkan masyarakat. Konsep diri yang negatif akan membuat remaja cenderung melanggar peraturan dan norma-norma masyarakat dan akhirnya terlibat dalam kenakalan remaja Coopersmith (Muawanah, 2012).

Diharapkan hasil penelitian ini dapat memberikan implikasi kepada berbagai pihak seperti orang tua, pemerintah, masyarakat dan peneliti selanjutnya, seperti halnya dengan mengarahkan anak jalanan ke lingkungan yang lebih positif dengan memberikan bimbingan agar mereka dapat memahami konsep diri yang mereka terapkan dalam kehidupan sehari-hari. Untuk itu pentingnya penelitian ini dilakukan agar dapat menjadi bahan masukan kepada pemerintah Kota Salatiga agar bisa mengatasi permasalahan tentang keberadaan anak jalanan di kota Salatiga dan menekan angka kenakalan anak jalanan di kota Salatiga.

Penelitian ini memiliki beberapa keterbatasan diantaranya sampel yang digunakan dalam penelitian ini hanya menggunakan anak remaja saja, yang dimana anak jalanan di salatiga yang berusia dewasa cukup banyak, sampel yang digunakan dalam mengisi kuesioner masih sangat kurang hal ini dikarenakan jumlah anak jalanan usia remaja di Salatiga masih sedikit, variabel yang digunakan dalam penelitian belum mewakili semua faktor-faktor yang mempengaruhi terjadinya kenakalan remaja pada anak jalanan. Dengan ini diharapkan kepada peneliti selanjutnya yang memiliki ketertarikan untuk meneliti anak jalanan agar lebih dalam lagi untuk meneliti konsep diri yang diterapkan oleh setiap anak jalanan dengan lebih tajam dan mendalam. Dengan memungkinkan dilakukan dengan mengaitkan variabel psikologi lainnya yang ada pada anak remaja atau turunnya anak remaja ke jalanan.

\section{SIMPULAN}

Terdapat hubungan negatif yang signifikan antara variabel dengan konsep diri dengan kenakalan anak remaja pada anak jalanan khusunya di kota Salatiga. Semakin tinggi konsep diri maka semakin rendah kenakalan remaja pada anak jalanan. Sebaliknya semakin rendah konsep diri maka tingkat kenakalan remaja pada anak jalanan akan semakin tinggi. Konsep diri pada anak jalanan tergolong sedang 67.64 dengan mean 96.58. Tingkat kenakalan remaja pada anak jalanan Salatiga tergolong sedang $70.50 \%$ dengan mean sebesar 82 .

\section{DAFTAR RUJUKAN}

Chadwick, B. A., \& Top, B. L. (1993). Religiosity and Delinquency among LDS Adolescents. Journal for the Scientific Study of Religion, 32(1), 51-67.

Direktorat Bina Pelayanan Jiwa Depertemen Kesehatan. 2007. Buku Pedoman Pendampingan Psikologi Anak Jalanan. Jakarta: Departemen Kesehatan RI.

Djaali. 2008.Psikologi Pendidikan. Jakarta: Bumi Aksara.

Fernanda, M. M., \& Sano, A, 2012. Hubungan antara Kemampuan Berinteraksi Sosial dengan Hasil belajar Konselor, 1(2). 
Ghufron \& Risnawita.(2011).Teori-teori Psikologi.Yogyakarta: Ar-Ruzz Madia.

Hartina, S. (2019). Hubungan Konsep Diri dengan Kemampuan Perencanaan Karir Peserta Didik Kelas XI di MA AL-Hikmah Bandar Lampung Tahun Ajaran 2018/2019. Universitas Islam Negeri Raden Intan Lampung.

Karyati, S. (2017). Lingkungan Sosial, Teman Sebaya, Spiritualitas dan Perilaku Seksual Pranikah Remaja Anak Jalanan. The 5th Urecol Proceeding, 1418-1425.

Kurniasari, F. M., Khasanah, U., \& Kalimah, S. (2019). "Sexual Addiction" Sebuah Studi Literatur Penerapan Konsep Diri Anak Jalanan. Seminar Nasional INOBALI, 334-340. https://eproceeding.undwi.ac.id/index.ph p/inobali/article/view/77

Lubis, H., \& Hodriani. (2016). Profil Kehidupan Anak Jalanan di Kota Pematangsiantar. JPPUMA: Jurnal Ilmu Pemerintahan Dan Sosial Politik UMA (Journal of Governance and Political Social UMA), 4(1), 107-119.

Mahanani, D. P. (2010). Konsep Diri Anak Jalanan (Studi Kasus Pada Anak Jalanan di Yogyakarta). In Psikologi Universitas Islam Negeri Sunan Kalijaga. Universitas Islam Negeri Sunan Kalijaga Yogyakarta.

Mandel, N., \& Smeesters, D. (2008). The Sweet Escape: Effects of Mortality Salience on Consumption Quantities for High- and Low-Self-Esteem Consumers. Journal of Consumer Research, 35(2), 309-323. https://doi.org/10.1086/587626

Muawanah, L. B., Suroso., Pratikto,H. (2012) Kematangan Emosi, Konsep Diri Dan Kenakalan Remaja, 1(1) 6-14

Pamuchtia, Y., \& Pandjaitan, N. K. (2010). Konsep Diri Anak Jalanan : Kasus Anak Jalanan di Kota Bogor Provinsi Jawa
Barat. Sodality: Jurnal Transdisiplin

Papilia, D.E, Old, S.W., \& Felman, R.D. (2004). Human Development ( $9^{\text {th }}$ ed). New York:McGraw Hill

Pardede, Y. O. K. (2008). Konsep Diri Anak Jalanan Usia Remaja. Jurnal Ilmiah Psikologi Gunadarma, 1(2), 146-151.

Purwanto, W. T. (2017). Konsep Diri Anak Jalanan Usia Remaja [Universitas Muhammadiyah Malang]. https://doi.org/10.23916/08439011

Purwoko, T. (2013). Analisis Faktor-faktor Penyebab Keberadaan Anak Jalanan Di Kota Balikpapan. EJournal Sosiologi, l(4), 13-25

Razali, A., \& Razali, N. A. (2013). ParentChild Communication and Self Concept among Malays Adolescence. Asian Social Science, 9(11), 189-200. https://doi.org/10.5539/ass.v9n11p189

Riyadi, A. (2016). Hubungan Konsep Diri dengan Kenakalan Anak Jalanan pada Rumah Singgah Putra Mandiri Semarang. Psympathic: Jurnal Ilmiah Psikologi, 3(1), 23-34. https://doi.org/10.15575/psy.v3i1.1097

Sugiyono, (2013). Statistika Untuk Penelitian. Bandung: Alfabeta.

S, R. P. F., \& Oktaviani, Y. (2019). Faktor yang Mempengaruhi Perilaku Kenakalan Remaja pada Siswa-Siswi MAN 2 Model Kota Pekanbaru. Jomis (Journal Of Midwifery Science), 3(2), 84-90. 